\title{
Choroid Plexus Epithelium
}

National Cancer Institute

\section{Source}

National Cancer Institute. Choroid Plexus Epithelium. NCI Thesaurus. Code C42079.

The epithelium of the choroid plexus; which consists of cuboidal cells. 